\title{
Rational budgeting approach as a nutrient management tool for mixed crop-swine farms in Korea
}

\author{
Arif Reza ${ }^{1,2, a}$, Soomin Shim ${ }^{1, a}$, Seungsoo Kim¹, Sungil Ahn', Seunggun Won ${ }^{3}$, and Changsix Ra $^{1, *}$
}

* Corresponding Author: Changsix Ra Tel: +82-33-250-8618, Fax: +82-33-251-7719,

E-mail: changsix@kangwon.ac.kr

'Department of Animal Industry Convergence, College of Animal Life Science, Kangwon National University,

Chuncheon 24341, Korea

2 Department of Environmental Science, College of Agricultural Sciences, IUBAT-International University of Business Agriculture and Technology, Dhaka 1230, Bangladesh

${ }^{3}$ Department of Animal Resources, College of Life and Environmental Science, Daegu University, Gyeongsan 38453 , Korea

a These authors contributed equally to this work.

ORCID

Arif Reza

https://orcid.org/0000-0003-3193-2997

Soomin Shim

https://orcid.org/0000-0003-1288-9719

Seungsoo Kim

https://orcid.org/0000-0002-6838-4907

Sungil Ahn

https://orcid.org/0000-0001-8229-6420

Seunggun Won

https://orcid.org/0000-0003-2875-0789

Changsix Ra

https://orcid.org/0000-0002-2814-7544

Submitted Aug 12, 2019; Revised Oct 14, 2019; Accepted Nov 14, 2019
Objective: Due to rapid economic return, mixed crop-swine farming systems in Korea have become more intensive. Intensive farming practices often cause nutrient surpluses and lead to environmental pollution. Nutrient budgets can be used to evaluate the environmental impact and as a regulatory policy instrument for nutrient management. This study was conducted to select a nutrient budgeting approach applicable to the mixed crop-swine farms in Korea and suggest an effective manure treatment method to reduce on-farm nutrient production.

Methods: In this study, we compared current and ideal gross nutrient balance (GNB) approaches of Organisation for Economic Co-operation and Development and soil system budget (SSB) approach with reference to on-farm manure treatment processes. Data obtained from farm census and published literature were used to develop the farm nutrient budgets.

Results: The average nitrogen $(\mathrm{N})$ and phosphorus $(\mathrm{P})$ surpluses were approximately 11 times and over 7 times respectively higher in the GNB approaches than the SSB. After solid-liquid separation of manure, during liquid composting a change in aeration method from intermittent to continuous reduced the $\mathrm{N}$ and $\mathrm{P}$ loading about $50 \%$ and $47 \%$, respectively. Although changing in solid composting method from turning only to turning+aeration improved the $\mathrm{N}$ removal efficiency by $30.5 \%$, not much improvement in P removal efficiency was observed. Conclusion: Although the GNB approaches depict the impact of nutrients produced in the mixed crop-swine farms on the overall agricultural environment, the SSB approach shows the partitioning among different nutrient loss pathways and storage of nutrients within the soil system; thus, can help design sustainable nutrient management plans for the mixed cropswine farms. The study also suggests that continuous aeration for liquid composting and turning+aeration for solid composting can reduce nutrient loading to the soil.

Keywords: Nutrient Budget; Nutrient Management; Mixed Crop-swine Farm; Korea

\section{INTRODUCTION}

Combining crops with livestock at the farm level is known as a way of using nutrients more efficiently. Mixed crop-livestock farming practice increases food production by facilitating higher level of integration between crop and livestock production systems [1]. Intensification in mixed crop-livestock farming system increases agricultural production, but at a substantially higher environmental cost. Excessive nutrient inputs from livestock manure in intensive mixed crop-livestock farming systems often cause nutrient surpluses and lead to water and air pollution. A balance between inputs and outputs is therefore necessary to ensure both productivity and sustainability for intensively managed agroecosystems. Nutrient budgets have been used to understand nutrient cycling in agroecosystems as well as environmental indicators and regulatory policy instruments for nutrient management [2].

Nutrient budgets are developed based on the principle of 'conservation of matter' and 
widely used in environmental and socioeconomic studies. In many countries, nutrient budgets are incorporated as voluntary and mandatory regulations in nutrient management plans. Although nutrient budgets have been in practice for more than a century, well-documented and globally acceptable procedures are not available [2]. For instance, the European Union (EU) member countries use more than 50 different nutrient budgeting methods [3]. Considering the above, the current gross nutrient balance (GNB) approach developed by the Organisation for Economic Co-operation and Development has been acknowledged as a robust and reliable method for estimating nutrient budget by researchers and policymakers. However, the current GNB approach has some limitations and is not applicable in all circumstances [4]. Therefore, more detailed and need-based nutrient budgeting approaches are required to develop a sustainable nutrient management plan.

Along with economic development, agricultural practices in Korea have become more intensive and mixed crop-livestock farming systems are getting more popular. According to Statistics Korea, more than $82 \%$ of the livestock farms in Korea include croplands although the area is usually limited [5]. However, there are no nutrient management plan available for these mixed crop-livestock farms due to lack of proper nutrient budgeting approach. Rapid industrialization in swine farms is resulted in an increase of swine population from around 3.6 million in 1983 to 11.3 million in 2018 with a concomitant increase in manure production [5]. The Korean government has regulations such as the prohibition of direct use of livestock manure on agricultural land and stringent nutrient concentration limits in compost and effluents of livestock wastewater treatment process to reduce nutrient loading from livestock manures and protect the environment. The swine production and manure management system in Korea is quite different compared to other countries due to climatic conditions and the limited available arable land [6]. Swine manure in Korea is usually segregated into solid and liquid phases and composted prior to land application. Composting process (both solid and liquid) is generally carried out within the farms to reduce the environmental impact of land spreading of swine manure. Solid composting is done by aeration and turning+aeration (TA) method, while the liquid composting process is operated under continuous, intermittent, and no-aeration [6]. However, there is widespread speculation about the livestock sector in Korea that, nutrient loading from livestock manure is the main reason for water quality deterioration and soil nutrient surpluses. Nutrient budgets can therefore be used to evaluate both the environmental impact and sustainability of mixed crop-swine farming systems. Till now, most of the nutrient budgets in Korea were either developed at regional or watershed or field-scale from the biogeochemical perspective [7-9], but none of the studies reflected the real livestock manure treat- ment scenario in Korea. This present study was therefore conducted to ascertain a budgeting approach suitable for the mixed crop-swine farming system in Korea considering the manure treatment methods and suggest an effective manure treatment method to reduce on-farm nutrient loading to the soil.

\section{MATERIALS AND METHODS}

\section{Nutrient budget methodology}

In this study, we compared the current and ideal GNB approaches and the soil system budget (hereafter referred to as SSB) approach with particular reference to on-farm manure treatment processes to ascertain a suitable nutrient budgeting approach for the mixed crop-swine farms in Korea. The GNB (current and ideal) and SSB approaches are quite different in their system boundaries. The GNB approach considers extended soil surface as system boundary and includes nutrient losses from livestock barns and manure management systems to the air, water and soil environment, indicating overall environmental impact. The SSB approach provides detailed information on all the nutrient inputs, outputs including atmospheric (in the case of nitrogen $[\mathrm{N}]$ ) and hydrologic (for both $\mathrm{N}$ and phosphorus [P]) loss of nutrients from the soil and identifies the major nutrient loss pathways. All the components and subcomponents of the nutrient budgets are shown in the Table 1 ( $a$ and b). Due to lack of data, components including inputs from crop residues, mineralization and outputs through fodder production and crop residues and immobilization were not considered in this study. The strengths and shortcomings of each budgeting approach were also discussed in brief.

Data obtained from farm census and lab estimation together with data collected from the published literature were used to construct the farm nutrient budgets [6,7,9-21]. Nutrient fluxes were used to convert the different components of the nutrient budgets from their original reported unit to common units (Table 2). Most of the fluxes used in this study were derived from the studies focused on Korea [6,7,9-14]. Seed nutrient inputs fluxes were obtained from Kremer [15]. No studies have reported $\mathrm{N}$ fluxes for denitrification from chemical fertilizer and compost in Korea, we therefore used denitrification fluxes for industrialized countries reported by Bouwman et al [16]. Due to lack of studies on N leaching losses from upland agricultural fields in Korea, leaching loss flux was derived from Takakai et al [21].

\section{Research design}

This study was conducted in 2016 based on a set of three case study sites located in three different cities (Chuncheon, Hongcheon, Hwacheon) in Gangwon province, Korea. The multiple case study method was selected to represent a variety of mixed 
Table 1. Components of current and ideal GNB approaches and SSB approach to nutrient budgeting in mixed crop-swine farms used in this study

\begin{tabular}{|c|c|c|}
\hline Current GNB of OECD & Ideal GNB of OECD & SSB \\
\hline \multicolumn{3}{|l|}{ (a) N budget } \\
\hline \multicolumn{3}{|l|}{ Input } \\
\hline$\left(\mathrm{N}_{\mathrm{N} 1}\right)$ Chemical fertilizer & $\left(\mathrm{N}_{\mathrm{N} 1}\right)$ Chemical fertilizer & $\left(\mathrm{N}_{\mathrm{N} 1}\right)$ Chemical fertilizer \\
\hline$\left(\mathrm{N}_{\mathrm{N} 2}\right)$ Livestock manure & $\left(\mathrm{N}_{\mathrm{N} 2}\right)$ Livestock manure & $\left(\mathrm{N}_{\mathrm{N2}}\right)$ Compost (solid and liquid) \\
\hline$\left(\mathrm{N}_{\mathrm{N} 3}\right)$ Net manure import/export, withdrawals, stocks & $\left(\mathrm{N}_{\mathrm{N} 3}\right)$ Net manure import/export, withdrawals, stocks & $\mathbb{I N}_{\mathrm{N3}}$ ) Organic fertilizer ${ }^{1)}$ \\
\hline$\left(N_{N 4}\right)$ Organic fertilizer ${ }^{1)}$ & $\left.\mathbb{I N}_{N 4}\right)$ Organic fertilizer ${ }^{1)}$ & $\left(N_{N 4}\right)$ Biological $N$ fixation \\
\hline $\left.\mathrm{IN}_{\mathrm{N} 5}\right)$ Biological N fixation & $\mathrm{IN}_{\mathrm{N} 5}$ ) Biological N fixation & $\mathrm{IN}_{\mathrm{N}}$ ) Atmospheric deposition \\
\hline $\left.\mathrm{IN}_{\mathrm{N} 6}\right)$ Atmospheric deposition & $\left.\mathrm{IN}_{\mathrm{N} 6}\right)$ Atmospheric deposition & $\left(\mathrm{N}_{\mathrm{N} 6}\right)$ Mineralization \\
\hline \multirow[t]{2}{*}{$\left.\mathrm{IN}_{\mathrm{N} 7}\right)$ Planting materials } & $\left.\mathrm{IN}_{\mathrm{N} 7}\right)$ Planting materials & $\left(\mathrm{N}_{\mathrm{N}}\right)$ Planting materials \\
\hline & $\left(\mathrm{N}_{\mathrm{N} 8}\right)$ Crop residues & \\
\hline Total inputs $=$ & Total inputs $=$ & Total inputs $=$ \\
\hline $\operatorname{Sum}\left(I N_{N 1}, I N_{N 2}, I N_{N 3}, I N_{N 4}, I N_{N 5}, I N_{N 6}, I N_{N 7}\right)$ & 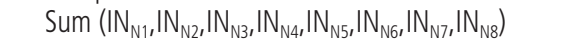 & $\operatorname{Sum}\left(\mathrm{IN}_{\mathrm{N} 1}, \mathrm{IN} \mathrm{N}_{\mathrm{N} 2}, \mathrm{IN}_{\mathrm{N} 3}, \mathrm{I} \mathrm{N}_{\mathrm{N} 4}, \mathrm{~N}_{\mathrm{N} 5}, \mathrm{I}_{\mathrm{N} 6}, \mathrm{I} \mathrm{N}_{\mathrm{N} 7}\right)$ \\
\hline \multicolumn{3}{|l|}{ Output } \\
\hline $\left.\mathrm{OUT}_{\mathrm{N} 1}\right)$ Crop production & $\mathrm{OUT}_{\mathrm{N1}}$ ) Crop production & $\mathrm{OUT}_{\mathrm{N} 1}$ ) Crop production \\
\hline $\mathrm{OUT}_{\mathrm{N2}}$ ) Fodder production ${ }^{2)}$ & $\mathrm{OUT}_{\mathrm{N2}}$ ) Fodder production ${ }^{2)}$ & $\left.\mathrm{OUT}_{\mathrm{N} 2}\right) \mathrm{NH}_{3}$ volatilization \\
\hline \multirow[t]{4}{*}{ OUT $_{\mathrm{N} 3}$ ) Crop residues } & $\left.\mathrm{OUT}_{\mathrm{N} 3}\right)$ Crop residues & $\mathrm{OUT}_{\mathrm{N} 3}$ ) Denitrification \\
\hline & $\mathrm{OUT}_{\mathrm{N} 4}$ ) Stock changes of $\mathrm{N}$ in soil & OUT $_{N 4}$ ) Leaching \\
\hline & & OUT $_{\text {N5 }}$ ) Runoff \\
\hline & & $\mathrm{OUT}_{\mathrm{N} 6}$ ) Immobilization \\
\hline Total outputs $=$ & Total outputs $=$ & Total outputs $=$ \\
\hline $\operatorname{Sum}\left(\mathrm{OUT}_{\mathrm{N} 1}, \mathrm{OUT}_{\mathrm{N} 2}, \mathrm{OUT}_{\mathrm{N} 3}\right)$ & $\operatorname{Sum}\left(\mathrm{OUT}_{\mathrm{N} 1}, \mathrm{OUT}_{\mathrm{N} 2}, \mathrm{OUT}_{\mathrm{N} 3}, \mathrm{OUT}_{\mathrm{N} 4}\right)$ & $\operatorname{Sum}\left(\mathrm{OUT}_{\mathrm{N} 1}, \mathrm{OUT}_{\mathrm{N} 2}, \mathrm{OUT}_{\mathrm{N} 3}, \mathrm{OUT}_{\mathrm{N} 4}, \mathrm{OUT}_{\mathrm{N} 5}, \mathrm{OUT}_{\mathrm{N} 6}\right)$ \\
\hline \multicolumn{3}{|l|}{ Surplus } \\
\hline \multirow[t]{6}{*}{$\mathrm{SP}_{\mathrm{N} 1}$ ) Gross N surplus (input-output) } & $\mathrm{SP}_{\mathrm{N} 1}$ ) Gross N surplus (input-output) & $\left.S P_{N 1}\right) N$ surplus (input-output) \\
\hline & $\left.\mathrm{SP}_{\mathrm{N} 2}\right)$ Atmospheric gross nitrogen surplus & \\
\hline & $\left.\mathrm{SP}_{\mathrm{N2-1}}\right) \mathrm{N}$ loss before application in the soil & \\
\hline & $\left.\mathrm{SP}_{\mathrm{N2}-2}\right) \mathrm{N}$ loss after application soil & \\
\hline & $\left.\mathrm{SP}_{\mathrm{N} 3}\right)$ Hydrologic gross $N$ surplus & \\
\hline & $\left(\mathrm{SP}_{\mathrm{N} 1}-\mathrm{SP}_{\mathrm{N} 2}\right)$ & \\
\hline \multicolumn{3}{|l|}{ (b) $\mathrm{P}$ budget } \\
\hline \multicolumn{3}{|l|}{ Input } \\
\hline $\left.\mid N_{P 1}\right)$ Chemical fertilizer & $\left(N_{p 1}\right)$ Chemical fertilizer & $\left(N_{P 1}\right)$ Chemical fertilizer \\
\hline$\left(N_{P 2}\right)$ Livestock manure & $\left(N_{P 2}\right)$ Livestock manure & $\left(N_{P 2^{\prime}}\right)$ Compost (solid and liquid) \\
\hline$\left(N_{P 3}\right)$ Net manure import/export, withdrawals, stocks & $\left(N_{P 3}\right)$ Net manure import/export, withdrawals, stocks & $\left(N_{p 3}\right)$ Organic fertilizer ${ }^{1)}$ \\
\hline$\left(N_{p 4}\right)$ Organic fertilizer ${ }^{1)}$ & $\left(N_{p 4}\right)$ Organic fertilizer ${ }^{11}$ & $\left(N_{P 4}\right)$ Atmospheric deposition \\
\hline $\left.\mathrm{IN}_{\mathrm{PS}}\right)$ Atmospheric deposition & $\left(N_{P 5}\right)$ Atmospheric deposition & $\left(\mathrm{N}_{\mathrm{P} 5}\right)$ Mineralization \\
\hline \multirow[t]{2}{*}{$\left.\mathrm{IN}_{\mathrm{P}}\right)$ Planting materials } & $\mathrm{IN}_{\mathrm{p} 6}$ ) Planting materials & $\left(N_{p 6}\right)$ Planting materials \\
\hline & $\left(N_{p 7}\right)$ Crop residues & \\
\hline Total inputs $=$ & Total inputs $=$ & Total inputs $=$ \\
\hline 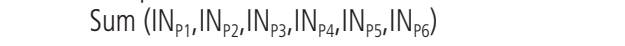 & Sum $\left(I N_{P 1}, I N_{P 2}, \mid N_{P 3}, I N_{P 4}, I N_{P 5}, I N_{P 6}, I N_{P 7}\right)$ & Sum $\left(I N_{P 1}, I N_{P 2},\left|N_{P 3}, I N_{P 4}, I N_{P 5},\right| N_{P 6}\right)$ \\
\hline \multicolumn{3}{|l|}{ Output } \\
\hline OUT $_{\mathrm{P} 1}$ ) Crop production & $\left.\mathrm{OUT}_{\mathrm{p} 1}\right)$ Crop production & OUT $\left._{P_{1}}\right)$ Crop production \\
\hline $\mathrm{OUT}_{\mathrm{P} 2}$ ) Fodder production ${ }^{2)}$ & OUT $_{P_{2}}$ ) Fodder production ${ }^{2)}$ & $\mathrm{OUT}_{\mathrm{P}_{2}}$ ) Leaching \\
\hline \multirow[t]{2}{*}{ OUT $_{\mathrm{P} 3}$ ) Crop residues } & $\mathrm{OUT}_{\mathrm{N} 3}$ ) Crop residues & OUT $\left._{P 3}\right)$ Runoff \\
\hline & OUT $_{p 4}$ ) Stock changes of $P$ in soil & \\
\hline Total outputs $=$ & Total outputs $=$ & Total outputs $=$ \\
\hline Sum (OUT $\left.1, \mathrm{OUT}_{\mathrm{P} 2}, \mathrm{OUT}_{\mathrm{P} 3}\right)$ & Sum (OUT $\left.T_{p 1,}, \mathrm{OUT}_{\mathrm{p} 2}, \mathrm{OUT}_{\mathrm{p} 3}, \mathrm{OUT}_{\mathrm{p} 4}\right)$ & Sum (OUT $\left.T_{p 1}, \mathrm{OUT}_{\mathrm{p} 2}, \mathrm{OUT}_{\mathrm{p} 3}\right)$ \\
\hline \multicolumn{3}{|l|}{ Surplus } \\
\hline$\left.S P_{P_{1}}\right) P$ surplus (input-output) & $\left.S P_{P 1}\right) P$ surplus (input-output) & $\left.\mathrm{SP}_{\mathrm{P} 1}\right)$ P surplus (input-output) \\
\hline
\end{tabular}

GNB, Gross Nutrient Balance; OECD, Organisation for Economic Co-operation and Development; SSB, Soil System Budget; P, Phosphorus.

1) Not used in the farms. ${ }^{2)}$ Not produced in the farms.

crop-swine farming systems within different contexts including agricultural practices and major swine manure treatment methods. Information on farm practices was collected through farm census using extensive questionnaires. Table 3 shows general information about the investigated farms. Information on manure management practices and agricultural charac- 
Table 2. Values of nutrient fluxes from the literature used to calculate nutrient budgets in this study

\begin{tabular}{|c|c|c|c|}
\hline Variables & & Flux & References \\
\hline \multicolumn{4}{|l|}{$\mathrm{N}$ budget } \\
\hline \multirow[t]{2}{*}{ Seed N inputs } & Sesame & 0.4 kg/ha/yr & [15] \\
\hline & Corn & $4.4 \mathrm{~kg} / \mathrm{ha} / \mathrm{yr}$ & \\
\hline Biological N fixation & & $15.0 \mathrm{~kg} / \mathrm{ha} / \mathrm{yr}$ & {$[7]$} \\
\hline Atmospheric deposition & & $24.1 \mathrm{~kg} / \mathrm{ha} / \mathrm{yr}$ & [11] \\
\hline \multicolumn{4}{|l|}{ Atmospheric loss } \\
\hline Denitrification & & & [7] \\
\hline Chemical fertilizer & & $15.0 \%$ & \\
\hline Compost & & $13.0 \%$ & \\
\hline Arable land & & 3.0 kg/ha/yr & \\
\hline Volatilization & & & [16] \\
\hline Chemical fertilizer & & $14.0 \%$ & \\
\hline Compost & & $23.0 \%$ & \\
\hline \multicolumn{4}{|l|}{ Hydrologic loss } \\
\hline Leaching & & $26.5 \%$ & {$[21]$} \\
\hline Runoff & & $15.0 \%$ & {$[12]$} \\
\hline \multicolumn{4}{|l|}{$P$ budget } \\
\hline \multirow[t]{2}{*}{ Seed N inputs } & Sesame & $0.7 \mathrm{~kg} / \mathrm{ha} / \mathrm{yr}$ & [15] \\
\hline & Corn & 1.1 kg/ha/yr & \\
\hline Atmospheric deposition & & 0.59 kg/ha/yr & {$[9]$} \\
\hline Hydrologic loss & & & \\
\hline Leaching & & $35.3 \%$ & [13] \\
\hline Runoff & & $7.4 \%$ & {$[14]$} \\
\hline
\end{tabular}

$\mathrm{N}$, nitrogen; P, phosphorus.

teristics of the selected farms are presented in Tables 4 and 5 , respectively. Comparison of the different manure treatment methods was carried out to ascertain the most effective manure treatment method.

Quantifying nutrient inputs:

i) Nutrient inputs from seeds

Data on seed nutrient inputs fluxes were collected from Kremer [15] and were calculated as:

$$
\mathrm{N}_{\text {seed }}=\operatorname{Seed}_{\mathrm{N}} \times \mathrm{A}
$$

$$
\mathrm{P}_{\text {seed }}=\operatorname{Seed}_{\mathrm{P}} \times \mathrm{A}
$$

where $\mathrm{N}_{\text {seed }}$ and $\mathrm{P}_{\text {seed }}$ are the nutrient inputs from seed and planting materials $(\mathrm{kg} / \mathrm{yr}) ;$ Seed $_{\mathrm{N}}$ and Seed $\mathrm{P}_{\mathrm{P}}$ are the seed nutrient inputs fluxes $(\mathrm{kg} / \mathrm{ha} / \mathrm{yr})$; and $\mathrm{A}$ is the agricultural land area (ha).

ii) Nutrient inputs from chemical fertilizer

Interviews with farm owners were conducted to collect information on chemical fertilizer application (FA) rates. Among the farms, farm 2 practices organic farming and therefore does not use any chemicals during crop production. Data on chemical FA rate and nutrient content were obtained from the RDA [17]. The nutrient inputs from chemical fertilizer were calculated using the following equations:

$$
\begin{aligned}
& \mathrm{N}_{\text {fert }}=\mathrm{FA} \times \mathrm{C}_{\mathrm{N} \text { fert }} \times \mathrm{A} \\
& \mathrm{P}_{\text {fert }}=\mathrm{FA} \times \mathrm{C}_{\mathrm{P} \text { fert }} \times \mathrm{A}
\end{aligned}
$$

where $\mathrm{N}_{\text {fert }}$ and $\mathrm{P}_{\text {fert }}$ are the nutrient inputs from chemical fertilizer $(\mathrm{kg} / \mathrm{yr})$; FA is the fertilizer application rate $(\mathrm{kg} / \mathrm{ha} / \mathrm{yr})$, $\mathrm{C}_{\mathrm{N} \text { fert }}$ and $\mathrm{C}_{\mathrm{P} \text { fert }}$ are the fertilizer nutrient content (\%) and $\mathrm{A}$ is the agricultural land area for each crop (ha).

iii) Nutrient inputs from livestock manure

Data on using unit discharge fluxes of swine were obtained from the Ministry of Environment (MoE), Korea [10]. N and $\mathrm{P}$ content in swine manure were developed previously [6]. Information on bulking agents (BA) was collected during the farm census. $\mathrm{N}$ and $\mathrm{P}$ contents of the BA were obtained from the RDA [18]. The nutrient inputs from livestock manure were calculated using the following equations:

$$
\begin{aligned}
& \mathrm{N}_{\text {man }}=\mathrm{AH} \times \mathrm{D} \times \mathrm{C}_{\mathrm{N} \text { man }}+\mathrm{BA} \times \mathrm{C}_{\mathrm{Nbed}} \\
& \mathrm{P}_{\text {man }}=\mathrm{AH} \times \mathrm{D} \times \mathrm{C}_{\mathrm{P} \text { man }}+\mathrm{BA} \times \mathrm{C}_{\mathrm{Pbed}}
\end{aligned}
$$

where $\mathrm{N}_{\operatorname{man}}$ and $\mathrm{P}_{\text {man }}$ are the nutrient inputs from livestock

Table 3. Descriptive information for the farms investigated in this study

\begin{tabular}{lccc}
\hline Contents & Farm 1 & Farm 2 & Farm 3 \\
\hline Location & Chuncheon & Hongcheon & Hwacheon \\
Latitude & $37.8813^{\circ} \mathrm{N}$ & $37.6970^{\circ} \mathrm{N}$ & $38.1061^{\circ} \mathrm{N}$ \\
Longitude & $127.7300^{\circ} \mathrm{E}$ & $127.8887^{\circ} \mathrm{E}$ & $127.7067^{\circ} \mathrm{E}$ \\
Altitude $(\mathrm{mas}))^{1)}$ & 99 & 252 & 109 \\
Rainfall $(\mathrm{mm} / \mathrm{yr})$ & 1,351 & 1,162 & 1,350 \\
Mean annual temperature $\left({ }^{\circ} \mathrm{C}\right)$ & 11.4 & 11.2 & 11.4 \\
No. of animal (head) & 700 & 1,800 & 1,500 \\
Excretion rate $(\mathrm{kg} / \mathrm{head} / \mathrm{d})$ & & 5.1 & 2,792 \\
$\quad$ Manure production $\left(\times 10^{3} \mathrm{~kg} / \mathrm{yr}\right)$ & 1,303 & 3,350 & Rice hull \\
Bulking agent & - & Rice hull & 13.9 \\
Bulking agent usage $\left(\times 10^{3} \mathrm{~kg} / \mathrm{yr}\right)$ & - & 16.7 & 13.9 \\
\hline
\end{tabular}

\footnotetext{
1) Meters above sea level.
} 
Table 4. Information on manure management of the farms investigated in this study

\begin{tabular}{|c|c|c|c|}
\hline Manure handling practices and productio & & & \\
\hline Manure collection system & Slurry & Slurry & Slurry \\
\hline Moisture content of solid after separation (\%) & - & 85 & 85 \\
\hline \multicolumn{4}{|l|}{ Liquid compost } \\
\hline Surface area $\left(m^{2}\right)$ & 50 & 50 & 50 \\
\hline Production amount $\left(\times 10^{3} \mathrm{~kg} / \mathrm{yr}\right)$ & $1,209.4$ & $3,084.7$ & $2,668.9$ \\
\hline \multicolumn{4}{|l|}{ Solid compost } \\
\hline Production amount ( $\times 10^{3}$ kg/yr $)$ & - & 296 & 273.4 \\
\hline
\end{tabular}

Table 5. Agricultural characteristics of the farms investigated in this study

\begin{tabular}{lccccc}
\hline Items & Farm 1 & \multicolumn{2}{c}{ Farm 2 } & \multicolumn{2}{c}{ Farm 3 } \\
\hline Cultivated crop (s) & Sesame & Corn & Sesame & Corn & Sesame \\
Arable land (ha) & 0.66 & 1.65 & 1.65 & 0.93 & 1.39 \\
Chemical fertilizer (kg/ha/yr) & 100 & - & - & 120 & 80 \\
Growing season per yr & & & Single & & \\
Production (kg/ha) & 500 & 5,030 & 1,200 & 5,030 & 1,200 \\
\hline
\end{tabular}

manure $(\mathrm{kg} / \mathrm{yr})$; $\mathrm{AH}$ is the number of animals (head); $\mathrm{D}$ is unit discharge coefficient $(\mathrm{kg} / \mathrm{head} / \mathrm{yr}) ; \mathrm{C}_{\mathrm{N} \text { man }}$ and $\mathrm{C}_{\mathrm{P} \operatorname{man}}$ are the nutrient content in swine manure $(\mathrm{g} / \mathrm{kg})$; BA is the bulking agent $(\mathrm{kg})$ and $\mathrm{C}_{\mathrm{N} \text { bed }}$ and $\mathrm{C}_{\mathrm{P} \text { bed }}$ are the nutrient content in $\mathrm{BA}(\mathrm{g} / \mathrm{kg})$.

iv) Nutrient inputs from compost

Swine farms in Korea segregate the swine manure into solid and liquid phases and following segregation, manure is composted [6]. Unit discharge fluxes for both solid (feces) and liquid (urine + wastewater) published by the MoE, Korea [10] were used to calculate individual farm manure production. Among the investigated farms, farm 1 does not have solid compost processing facility, whereas farm 2 and farm 3 have the both (solid and liquid) composting facilities. $\mathrm{N}$ and $P$ content in swine manure (solid and liquid) and nutrient loading fluxes from solid and liquid manure were developed previously [6]. For ease of calculation, we assumed that nutrient produced in the farms are applied to the farm arable land. The following equations were used to estimate the $\mathrm{N}$ and $\mathrm{P}$ inputs from compost:

$$
\begin{aligned}
& \mathrm{N}_{\text {com }}=\mathrm{N}_{\mathrm{sc}}+\mathrm{N}_{\mathrm{lc}} \\
& \mathrm{P}_{\text {com }}=\mathrm{P}_{\mathrm{sc}}+\mathrm{P}_{\mathrm{lc}}
\end{aligned}
$$

where $\mathrm{N}_{\text {com }}$ and $\mathrm{P}_{\text {com }}$ are the total nutrient inputs from compost ( $\mathrm{kg} / \mathrm{yr}) ; \mathrm{N}_{\mathrm{sc}}$ and $\mathrm{N}_{\mathrm{lc}}$ are the $\mathrm{N}$ inputs from solid and liquid compost $(\mathrm{kg} / \mathrm{yr})$, respectively and $\mathrm{P}_{\mathrm{sc}}$ and $\mathrm{P}_{\mathrm{lc}}$ are the $\mathrm{P}$ inputs from solid and liquid compost $(\mathrm{kg} / \mathrm{yr})$, respectively. Nutrient inputs from solid and liquid compost were calculated separately using the equations below:

(i) Nutrient production from solid composts

$$
\begin{aligned}
& \mathrm{N}_{\mathrm{sc}}=\left(\mathrm{AH} \times \mathrm{D}_{\mathrm{s}} \times \mathrm{C}_{\mathrm{N}} \times \mathrm{LC}_{\mathrm{N}}\right)+\mathrm{BA} \\
& \mathrm{P}_{\mathrm{sc}}=\left(\mathrm{AH} \times \mathrm{D}_{\mathrm{s}} \times \mathrm{C}_{\mathrm{P}} \times \mathrm{LC}_{\mathrm{P}}\right)+\mathrm{BA}
\end{aligned}
$$

where $\mathrm{N}_{\mathrm{sc}}$ and $\mathrm{P}_{\mathrm{sc}}$ are the nutrient inputs from solid compost $(\mathrm{kg} / \mathrm{yr}) ; \mathrm{AH}$ is the number of animals (head); $\mathrm{D}_{\mathrm{s}}$ is the unit discharge coefficient for solid fraction $(\mathrm{kg} / \mathrm{head} / \mathrm{yr}) ; \mathrm{C}_{\mathrm{N}}$ and $\mathrm{C}_{\mathrm{P}}$ are the nutrient content in solid fraction after separation $(\mathrm{g} / \mathrm{kg}) ; \mathrm{LC}_{\mathrm{N}}$ and $\mathrm{LC}_{\mathrm{P}}$ are nutrient loading fluxes and $\mathrm{BA}$ is the bulking agent $(\mathrm{kg})$.

(ii) Inputs from liquid composts

$$
\begin{aligned}
& \mathrm{N}_{\mathrm{lc}}=\left(\mathrm{AH} \times \mathrm{D}_{\mathrm{l}} \times \mathrm{C}_{\mathrm{N}} \times \mathrm{LC}_{\mathrm{N}}\right) \\
& \mathrm{P}_{\mathrm{lc}}=\left(\mathrm{AH} \times \mathrm{D}_{\mathrm{l}} \times \mathrm{C}_{\mathrm{P}} \times \mathrm{LC}_{\mathrm{P}}\right)
\end{aligned}
$$

where $\mathrm{N}_{\mathrm{lc}}$ and $\mathrm{P}_{\mathrm{lc}}$ are the nutrient inputs from liquid compost $(\mathrm{kg} / \mathrm{yr}) ; \mathrm{AH}$ is the number of animals (head); $\mathrm{D}_{1}$ is unit discharge coefficient for liquid fraction $(\mathrm{kg} / \mathrm{head} / \mathrm{yr}) ; \mathrm{C}_{\mathrm{N}}$ and $\mathrm{C}_{\mathrm{P}}$ are the nutrient content in liquid fraction after separation $(\mathrm{g} / \mathrm{kg})$ and $\mathrm{LC}_{\mathrm{N}}$ and $\mathrm{LC}_{\mathrm{p}}$ are nutrient loading fluxes.

v) Nutrient inputs from atmospheric deposition

Values from previously published literature were used to estimate the $\mathrm{N}$ and $\mathrm{P}$ inputs from atmospheric deposition [9, 11] and expressed as:

$$
\begin{aligned}
& \mathrm{N}_{\mathrm{atm}}=\mathrm{AD}_{\mathrm{N}} \times \mathrm{A} \\
& \mathrm{P}_{\mathrm{atm}}=\mathrm{AD}_{\mathrm{P}} \times \mathrm{A}
\end{aligned}
$$

where $\mathrm{N}_{\mathrm{atm}}$ and $\mathrm{P}_{\mathrm{atm}}$ are the nutrient inputs from atmospheric deposition $(\mathrm{kg} / \mathrm{yr}) ; \mathrm{AD}_{\mathrm{N}}$ and $\mathrm{AD}_{\mathrm{P}}$ are the unit atmospheric 
deposition fluxes $(\mathrm{kg} / \mathrm{ha} / \mathrm{yr})$ and $\mathrm{A}$ is the agricultural land area (ha).

vi) Nitrogen input from biological nitrogen fixation

The amount of $\mathrm{N}$ input from biological nitrogen fixation (BNF) was calculated using standard values from the published literature [7] and the following equation was used for calculation:

$$
\mathrm{N}_{\mathrm{bnf}}=\mathrm{BNF} \times \mathrm{A}
$$

where $\mathrm{N}_{\text {bnf }}$ is the $\mathrm{N}$ input from $\mathrm{BNF}(\mathrm{kg} / \mathrm{yr})$; BNF the unit biological nitrogen fixation fluxes $(\mathrm{kg} / \mathrm{ha} / \mathrm{yr})$ and $\mathrm{A}$ is the agricultural land area (ha).

Quantifying nutrient outputs:

i) Outputs in harvested crops

Data on crop production were collected during farm census. $\mathrm{N}$ and $\mathrm{P}$ contents of the crops were obtained from the RDA [19]. The following equations were used to estimate nutrient outputs through crop harvesting:

$$
\begin{aligned}
& \mathrm{N}_{\text {crop }}=\mathrm{Pro}_{\text {crop }} \times \mathrm{C}_{\mathrm{N} \text { crop }} \times \mathrm{A} \\
& \mathrm{P}_{\text {crop }}=\mathrm{PrO}_{\text {crop }} \times \mathrm{C}_{\mathrm{P}_{\text {crop }}} \times \mathrm{A}
\end{aligned}
$$

where $\mathrm{N}_{\text {crop }}$ and $\mathrm{P}_{\text {crop }}$ are the nutrient outputs through crop harvesting $(\mathrm{kg} / \mathrm{yr}) ; \mathrm{Pro}_{\text {crop }}$ is the crop production $(\mathrm{kg} / \mathrm{ha} / \mathrm{yr})$; $\mathrm{C}_{\mathrm{N} \text { crop }}$ and $\mathrm{C}_{\mathrm{P} \text { crop }}$ are the estimated crop nutrient content (\%); $\mathrm{A}$ is the agricultural land area for each crop (ha).

ii) Changes in soil nutrient stocks

Data on soil nutrient stocks were obtained from RDA [20] and the following equations were used to estimate changes in soil nutrient stocks:

$$
\begin{aligned}
& \mathrm{N}_{\text {ssc }}=\left(\mathrm{N}_{\text {soil 2017 }}-\mathrm{N}_{\text {soil 2016 }}\right) \times \mathrm{A} \\
& \mathrm{P}_{\text {ssc }}=\left(\mathrm{P}_{\text {soil 2017 }}-\mathrm{P}_{\text {soil 2016 }}\right) \times \mathrm{A}
\end{aligned}
$$

where $\mathrm{N}_{\mathrm{ssc}}$ and $\mathrm{P}_{\mathrm{ssc}}$ are the soil nutrient stock changes $(\mathrm{kg} / \mathrm{yr})$; $\mathrm{N}_{\text {soil 2017 }}$ and $\mathrm{P}_{\text {soil 2017 }}$ are the soil $\mathrm{N}$ and $\mathrm{P}$ content in the year 2017 (kg/ha/yr), respectively; $\mathrm{N}_{\text {soil } 2016}$ and $\mathrm{P}_{\text {soil } 2016}$ are the soil $\mathrm{N}$ and $\mathrm{P}$ content in the year $2016(\mathrm{~kg} / \mathrm{ha} / \mathrm{yr})$; A is the agricultural land area of the farm (ha).

iii) Output in atmospheric losses (volatilization and denitrification)

$\mathrm{N}$ loss through volatilization and denitrification were estimated based on fluxes reported by Bouwman et al [16] and Bashkin et al [7] and calculated using the following formula:

(i) Volatilization loss:

$$
\mathrm{N}_{\text {vol }}=\mathrm{N}_{\text {fert }} \times \mathrm{V}_{\text {fert }}+\mathrm{N}_{\text {com }} \times \mathrm{V}_{\text {com }}
$$

where $\mathrm{N}_{\mathrm{vol}}$ is the nutrient output through volatilization $(\mathrm{kg} / \mathrm{yr})$;
$\mathrm{N}_{\text {fert }}$ is the nutrient input from chemical fertilizer $(\mathrm{kg} / \mathrm{yr})$; $\mathrm{V}_{\text {fert }}$ is the volatilization coefficient of for applied chemical fertilizer (\%); $\mathrm{N}_{\text {com }}$ is the nutrient input from compost $(\mathrm{kg} / \mathrm{yr}) ; \mathrm{V}_{\text {com }}$ is the volatilization coefficient for applied compost (\%).

(ii) Denitrification loss:

$$
\mathrm{N}_{\text {den }}=\mathrm{N}_{\text {fert }} \times \mathrm{D}_{\text {fert }}+\mathrm{N}_{\text {com }} \times \mathrm{D}_{\text {com }}+\mathrm{TA} \times \mathrm{D}_{\text {agri }}
$$

where $\mathrm{N}_{\mathrm{den}}$ is the nutrient output through denitrification $(\mathrm{kg} / \mathrm{yr}) ; \mathrm{N}_{\text {fert }}$ is the nutrient input from chemical fertilizer $(\mathrm{kg} / \mathrm{yr}) ; \mathrm{D}_{\text {fert }}$ is the denitrification coefficient for applied chemical fertilizer (\%); $\mathrm{N}_{\mathrm{com}}$ is the nutrient input from compost $(\mathrm{kg} / \mathrm{yr}) ; \mathrm{D}_{\text {com }}$ is the denitrification coefficient for applied compost (\%); TA is the total arable land area (ha); $\mathrm{D}_{\text {agri }}$ is the unit denitrification coefficient for arable land ( $\mathrm{kg} / \mathrm{ha} / \mathrm{yr})$.

iv) Outputs in hydrologic export (leaching and runoff)

Hydrologic export of nutrients was estimated in terms of leaching and runoff using fluxes derived from published literature [12-14,21] and expressed as:

(i) Nutrient export in leaching

$$
\begin{aligned}
& \mathrm{N}_{\text {leach }}=\mathrm{N}_{\text {input }} \times \mathrm{L}_{\mathrm{N}} \\
& \mathrm{P}_{\text {leach }}=\mathrm{N}_{\text {input }} \times \mathrm{L}_{\mathrm{P}}
\end{aligned}
$$

where $\mathrm{N}_{\text {leach }}$ and $\mathrm{P}_{\text {leach }}$ are the nutrient outputs in leaching $(\mathrm{kg} / \mathrm{yr}) ; \mathrm{N}_{\text {input }}$ and $\mathrm{P}_{\text {input }}$ are the total nutrient inputs $(\mathrm{kg} / \mathrm{yr})$; $\mathrm{L}_{\mathrm{N}}$ and $\mathrm{L}_{\mathrm{P}}$ are the nutrient leaching fluxes (\%).

(ii) Nutrient export in runoff

$$
\begin{aligned}
& \mathrm{N}_{\text {runoff }}=\mathrm{N}_{\text {input }} \times \mathrm{R}_{\mathrm{N}} \\
& \mathrm{P}_{\text {runoff }}=\mathrm{N}_{\text {input }} \times \mathrm{R}_{\mathrm{P}}
\end{aligned}
$$

where $\mathrm{N}_{\text {runoff }}$ and $\mathrm{P}_{\text {runoff }}$ are the nutrient outputs in runoff $(\mathrm{kg} / \mathrm{yr}) ; \mathrm{N}_{\text {input }}$ and $\mathrm{P}_{\text {input }}$ are the total nutrient inputs (kg/yr); $\mathrm{R}_{\mathrm{N}}$ and $\mathrm{R}_{\mathrm{P}}$ are the nutrient runoff fluxes (\%).

Nutrient balance:

After quantifying all the nutrient inputs and outputs, the nutrient balance (surplus/deficit) was estimated using the following mass balance equations:

$$
\begin{aligned}
& \text { N balance (surplus/deficit) } \\
& =\text { total inputs - total outputs } \\
& \text { P balance (surplus/deficit) } \\
& =\text { total inputs - total outputs }
\end{aligned}
$$

A positive nutrient balance indicates a nutrient surplus or potential for nutrient loss to the environment, while a negative nutrient balance signifies a nutrient deficit.

i) Atmospheric gross nitrogen surplus 
The atmospheric gross nitrogen surplus (aGNS) was the sum of $\mathrm{N}$ loss before application in the soil and $\mathrm{N}$ loss after application from the soil and expressed as:

$$
\mathrm{aGNs}=\mathrm{N}_{\mathrm{NLB}}+\mathrm{N}_{\mathrm{NLA}}
$$

where aGNS is the atmospheric gross nitrogen surplus $(\mathrm{kg} / \mathrm{yr})$; $\mathrm{N}_{\mathrm{NLB}}$ is the $\mathrm{N}$ loss before application in the soil ( $\left.\mathrm{kg} / \mathrm{yr}\right)$ and $\mathrm{N}_{\mathrm{NLA}}$ is the $\mathrm{N}$ loss after application from the soil (kg/yr). $\mathrm{N}$ loss before application in the soil and after application from the soil were calculated separately using the equations below:

(i) Nitrogen loss before application in the soil

$$
\mathrm{N}_{\mathrm{NLB}}=\mathrm{N}_{\text {man }}-\mathrm{N}_{\mathrm{com}}
$$

where $\mathrm{N}_{\mathrm{NLB}}$ is the $\mathrm{N}$ loss before application in the soil ( $\left.\mathrm{kg} / \mathrm{yr}\right)$; $\mathrm{N}_{\text {man }}$ is the $\mathrm{N}$ input from livestock manure $(\mathrm{kg} / \mathrm{yr}) ; \mathrm{N}_{\text {com }}$ is the $\mathrm{N}$ input from compost $(\mathrm{kg} / \mathrm{yr})$.

(ii) Nitrogen loss after application in the soil

$$
\mathrm{N}_{\mathrm{NLA}}=\mathrm{N}_{\mathrm{vol}}+\mathrm{N}_{\mathrm{den}}
$$

where $\mathrm{N}_{\mathrm{NLA}}$ is the $\mathrm{N}$ loss after application in the soil $(\mathrm{kg} / \mathrm{yr})$;
$\mathrm{N}_{\mathrm{vol}}$ is the $\mathrm{N}$ output through volatilization $(\mathrm{kg} / \mathrm{yr}) ; \mathrm{N}_{\text {den }}$ is the $\mathrm{N}$ output through denitrification $(\mathrm{kg} / \mathrm{yr})$.

ii) Hydrologic gross nitrogen surplus

The hydrologic gross nitrogen surplus (hGNS) is estimated by deducting the aGNS from gross nitrogen surplus (GNS) and expressed as:

$$
\text { hGNs }=\text { GNS }- \text { aGNS }
$$

\section{RESULTS AND DISCUSSION}

\section{Nutrient budgets for individual farms}

Based on Tables 1 ( $\mathrm{a}, \mathrm{b})$, and 2, the $\mathrm{N}$ and $\mathrm{P}$ budgets for the mixed crop-swine farms were developed and are shown in Tables 6 and 7, respectively. Major sources of both nutrient inputs and outputs differ substantially according to the manure recycling processes and treatment methods used by the respective farms. The detailed explanations of nutrient budgets are described in the following subsections.

Nitrogen budgets: Table 6 shows the nitrogen budgets for the investigated farms using current and ideal GNB appro-

\begin{tabular}{|c|c|c|c|c|c|c|c|c|c|}
\hline \multirow{3}{*}{ Items } & \multicolumn{9}{|c|}{ Amount (kg N/yr) } \\
\hline & \multicolumn{3}{|c|}{ Farm-1 } & \multicolumn{3}{|c|}{ Farm-2 } & \multicolumn{3}{|c|}{ Farm-3 } \\
\hline & Current GNB & Ideal GNB & SSB & Current GNB & Ideal GNB & SSB & Current GNB & Ideal GNB & SSB \\
\hline Chemical fertilizer & 8.0 & 8.0 & 8.0 & - & - & - & 16.0 & 16.0 & 16.0 \\
\hline Livestock manure & $11,075.9$ & $11,075.9$ & & $28,480.9$ & $28,480.9$ & - & $23,734.1$ & $23,734.1$ & - \\
\hline Compost & - & - & - & - & - & - & - & - & - \\
\hline Liquid compost & - & - & $5,031.1$ & - & - & $12,832.6$ & - & - & $5,551.2$ \\
\hline Solid compost & - & - & & - & - & $1,363.8$ & - & - & $1,810.9$ \\
\hline Biological N fixation & 9.9 & 9.9 & 9.9 & 49.5 & 49.5 & 49.5 & 34.8 & 34.8 & 34.8 \\
\hline Atmospheric deposition & 15.9 & 15.9 & 15.9 & 79.5 & 79.5 & 79.5 & 55.9 & 55.9 & 55.9 \\
\hline Planting materials & 0.3 & 0.3 & 0.3 & 7.9 & 7.9 & 7.9 & 4.6 & 4.6 & 4.6 \\
\hline Total inputs & $11,110.0$ & $11,110.0$ & $5,065.2$ & $28,617.9$ & $28,617.9$ & $14,333.4$ & $23,845.4$ & $23,845.4$ & $7,473.4$ \\
\hline Crop harvesting & 26.4 & 26.4 & 26.4 & 88.6 & 88.6 & 88.6 & 68.4 & 68.4 & 68.4 \\
\hline Stock changes of $\mathrm{N}$ in soil & - & 40.9 & - & - & 57.5 & - & - & -46.5 & - \\
\hline Denitrification & - & - & - & - & - & - & - & - & - \\
\hline Chemical fertilizer & - & - & 1.2 & - & - & 0.0 & - & - & 2.4 \\
\hline Compost & - & - & 654.0 & - & - & $1,845.5$ & - & - & 957.1 \\
\hline Arable land & - & - & 2.0 & - & - & 9.9 & - & - & 7.0 \\
\hline Volatilization & - & - & - & - & - & - & - & - & - \\
\hline Chemical fertilizer & - & - & 1.1 & - & - & 0.0 & - & - & 2.2 \\
\hline Compost & - & - & $1,157.2$ & - & - & $3,265.2$ & - & - & $1,693.3$ \\
\hline Leaching & - & - & $1,342.3$ & - & - & $3,798.3$ & - & - & $1,980.5$ \\
\hline Runoff & - & - & 759.8 & - & - & $2,150.0$ & - & - & $1,121.0$ \\
\hline Total outputs & 26.4 & 67.3 & $3,943.9$ & 88.6 & 146.1 & $11,157.6$ & 68.4 & 21.9 & $5,831.8$ \\
\hline Gross N surplus & $11,083.6$ & $11,042.7$ & $1,121.2$ & $28,529.2$ & $28,471.7$ & $3,175.8$ & $23,777.1$ & $23,823.6$ & $1,641.6$ \\
\hline Atmospheric GNS & - & $6,044.8$ & - & - & $14,284.5$ & - & - & $16,372.0$ & - \\
\hline Hydrologic GNS & - & 4,997.9 & - & - & $14,187.2$ & - & - & $7,451.6$ & - \\
\hline
\end{tabular}
aches and SSB approach. In both GNB approaches, all the components of $\mathrm{N}$ inputs are same except $\mathrm{N}$ inputs from

Table $6 . \mathrm{N}$ budgets for the mixed crop-swine farm systems investigated in this study

GNB, gross nutrient balance; SSB, soil system budget; N, nitrogen; GNS, gross nitrogen surplus. 
Table 7. $P$ budgets for the mixed crop-swine farm systems investigated in this study

\begin{tabular}{|c|c|c|c|c|c|c|c|c|c|}
\hline \multirow{3}{*}{ Items } & \multicolumn{9}{|c|}{ Amount (kg P/yr) } \\
\hline & \multicolumn{3}{|c|}{ Farm-1 } & \multicolumn{3}{|c|}{ Farm-2 } & \multicolumn{3}{|c|}{ Farm-3 } \\
\hline & Current GNB & Ideal GNB & SSB & Current GNB & Ideal GNB & SSB & Current GNB & Ideal GNB & SSB \\
\hline Livestock manure & $1,954.6$ & $1,954.6$ & - & $5,026.1$ & $5,026.1$ & - & $4,188.4$ & $4,188.4$ & - \\
\hline Compost & - & - & - & - & - & - & - & - & - \\
\hline Atmospheric deposition & 0.4 & 0.4 & 0.4 & 1.9 & 1.9 & 1.9 & 1.4 & 1.4 & 1.4 \\
\hline Planting materials & 0.5 & 0.5 & 0.5 & 3.0 & 3.0 & 3.0 & 2.0 & 2.0 & 2.0 \\
\hline Total inputs & $1,963.5$ & $1,963.5$ & 81.5 & $5,031.0$ & $5,031.0$ & $1,212.9$ & $4,207.8$ & $4,207.8$ & $1,030.0$ \\
\hline Crop harvesting & 5.9 & 5.9 & 5.9 & 19.2 & 19.2 & 19.2 & 14.9 & 14.9 & 14.9 \\
\hline Stock changes of $\mathrm{P}$ in soil & - & -40.8 & - & - & -46.5 & - & - & 204.4 & - \\
\hline
\end{tabular}

GNB, gross nutrient balance; SSB, soil system budget; $P$, phosphorus.

livestock manure. Inputs from livestock manure were directly calculated by multiplying the livestock population with the excretion fluxes reported by MoE and were 11,075.9, $28,480.9$, and $23,734.1 \mathrm{~kg} / \mathrm{yr}$ for the farms 1, 2 and 3, respectively.

Whereas based on estimates, farms 1 and 2 produced 1,209.4 $\times 10^{3}$ and $3,084.7 \times 10^{3} \mathrm{~kg} / \mathrm{yr}$ of liquid compost, respectively using the intermittent aeration (IA) method, after separating solid fraction from the swine manure. Farm 3 produced 2,668.7 $\times 10^{3} \mathrm{~kg} / \mathrm{yr}$ of liquid compost using the continuous aeration (CA) method. The $\mathrm{N}$ content in the liquid compost was estimated as $8 \mathrm{~g} / \mathrm{kg}$, while loading fluxes varied substantially depending on the manure treatment method. $\mathrm{N}$ loading fluxes for liquid composts produced by IA and CA were 0.52 and 0.26 , respectively [6]. For solid composting, farm 2 used the TA method and produced $296 \times 10^{3} \mathrm{~kg} / \mathrm{yr}$ solid compost. On the other hand, farm 3 produced $273.39 \times 10^{3} \mathrm{~kg} / \mathrm{yr}$ solid compost using the turning $(\mathrm{T})$ only method. The $\mathrm{N}$ content in the solid compost was $9.6 \mathrm{~g} / \mathrm{kg}$ and loading fluxes for TA and $\mathrm{T}$ were estimated as 0.48 and 0.69 , respectively [6]. Total $\mathrm{N}$ inputs from compost were calculated as 5,031.1, 14,196.4, and 7,362.1 kg/yr in farms 1, 2 and 3, respectively.

$\mathrm{N}$ inputs from chemical fertilizer and seeds used for planting crops added a relatively small amount of $\mathrm{N}$ to the farms due to limited arable land. Chemical fertilizer added only 8.0 and $16.0 \mathrm{~kg} / \mathrm{yr}$ to farms 1 and 3, respectively. $\mathrm{N}$ inputs from the planting materials to farms 1,2 , and 3 were $0.3,7.9$, and $4.6 \mathrm{~kg} / \mathrm{yr}$, respectively. Other sources of $\mathrm{N}$ inputs to the farms were BNF and atmospheric deposition. In Korea, BNF for the dry field crops was estimated to be $15 \mathrm{~kg} / \mathrm{ha} / \mathrm{yr}$ [7] and amount of $\mathrm{N}$ fixed at the agricultural field in farms 1, 2 and 3 were 9.9, 49.5, and $34.8 \mathrm{~kg} / \mathrm{yr}$, respectively. Atmospheric deposition of $\mathrm{N}$ in Korea was estimated as $24.1 \mathrm{~kg} / \mathrm{ha} / \mathrm{yr}$ [11] and the amount of $\mathrm{N}$ inputs through atmospheric deposition were calculated as $15.9,79.5$, and $55.9 \mathrm{~kg} / \mathrm{yr}$ farms 1,2 and 3 , respectively.

Although the GNB approach is generally regarded as a sound method of nutrient budget calculation considering the $\mathrm{N}$ outputs through crop harvesting and soil $\mathrm{N}$ stock changes; nutrient losses from soil were not taken into accounts. The SSB approach elucidated that most of the $\mathrm{N}$ was lost from the farms through leaching, followed by volatilization, runoff, denitrification and crop harvesting. $\mathrm{N}$ losses due to leaching were calculated using data from Takakai et al [21]. Leaching losses accounted for $26.5 \%$ of the total input and calculated as $1,342.3,3,798.3$, and 1,980.5 kg/yr for farm 1, 2 and 3, respectively. While runoff loss of $\mathrm{N}$ was reported as $15 \%$ of the total $\mathrm{N}$ input [12] and yielding an annual $\mathrm{N}$ output of 759.8 , $2,150.0,1,121.0 \mathrm{~kg} / \mathrm{yr}$ from farms 1,2 and 3, respectively. Atmospheric loss of $\mathrm{N}$ due to denitrification was calculated as 657.2, 1,855.4, and 966.5 kg/yr for farms 1, 2 and 3, respectively using the estimates reported by Bashkin et al [7]. Of the total chemical fertilizer and compost applied in the field, $\mathrm{N}$ loss through volatilization was estimated as $14 \%$ and $23 \%$, respectively [16] and calculated as 1,158.3, 3,265.2, and 1,695.5 $\mathrm{kg} / \mathrm{yr}$ for farms 1, 2 and 3, respectively. $\mathrm{N}$ export in crop harvesting was $26.4,88.6$, and $68.4 \mathrm{~kg} / \mathrm{yr}$ for farms 1,2 and 3 , respectively.

Phosphorus budgets: P budgets for the selected farms using current and ideal GNB approaches and SSB approach are shown in Table 7. P inputs from swine manure were calculated as 1,954.6, 5,026.1, and 4,188.4 kg/yr. P levels in the liquid compost and solid compost were estimated as 0.4 and $3.6 \mathrm{~g} / \mathrm{kg}$, respectively and loading fluxes from liquid compost 
using IA and CA were 0.15 and 0.08, respectively [6]. Despite differences in treatment methods (TA and $\mathrm{T}$ ) for solid composts, the loading fluxes did not vary much and reported as 0.94 and 0.96, respectively. Annual P inputs to farms 1, 2 and 3 were therefore calculated as $72.6,1,208.0$, and $1,010.6 \mathrm{~kg} /$ $\mathrm{yr}$, respectively. Through chemical fertilizers, farms 1 and 3 received only 8.0 and $16.0 \mathrm{~kg} \mathrm{P} / \mathrm{yr}$, respectively. Annual P inputs from seeds to the farms $(1,2$, and 3$)$ were calculated as $0.5,3.0$, and $2.0 \mathrm{~kg} / \mathrm{yr}$, respectively. Atmospheric deposition of $\mathrm{P}$ was estimated as $0.59 \mathrm{~kg} / \mathrm{ha} / \mathrm{yr}$ [9], which equivalent to $0.4,1.9$, and $1.4 \mathrm{~kg} / \mathrm{yr}$ of $\mathrm{P}$ inputs to farm 1,2 and 3 , respectively.

The current GNB approach considered crop harvesting as the only pathway of P outputs, while in the Ideal GNB approach soil stock changes of $\mathrm{P}$ were also included. The SSB approach showed that most of the P left the farms through leaching, followed by crop harvesting and runoff. Of the total P applied, Kang et al [13] reported that 35.3\% was lost due to leaching, corresponding to an amount of 28.8, 428.2, and $363.6 \mathrm{~kg} / \mathrm{yr}$ for farms 1, 2 and 3, respectively. Runoff losses were calculated as $7.4 \%$ of the total input [14] and accounted for 6.0, 89.8, and $76.2 \mathrm{~kg} \mathrm{P} / \mathrm{yr}$ for farms 1,2 and 3, respectively. $\mathrm{P}$ export in crop harvesting was $5.9,19.2$, and $14.9 \mathrm{~kg} / \mathrm{yr}$ for the farm 1, 2 and 3, respectively.

\section{Trends in the nutrient budgets}

$\mathrm{N}$ budgets for farms 1,2 , and 3 varied significantly among the budgeting approaches. The estimated total $\mathrm{N}$ inputs to the farms 1, 2, and 3 using the GNB approaches were approximately $11,110.0,28,617.9$, and $23,845.4 \mathrm{~kg} / \mathrm{yr}$, respectively. While estimated using the SSB approach, the total $\mathrm{N}$ inputs were $5,065.2,14,333.4$, and 7,473.4 kg/yr for the farms 1,2 , and 3. As expected, anthropogenic $\mathrm{N}$ inputs through livestock manure/compost were the largest source of $\mathrm{N}$ in the farms in all cases. Other sources including chemical fertilizers, planting materials, BNF and atmospheric deposition added only a small portion to the inputs. The total $\mathrm{N}$ outputs calculated using the current GNB approach were approximately $26.4,88.6$, and $68.4 \mathrm{~kg} / \mathrm{yr}$, the ideal GNB approach were 67.3, 146.1 , and $21.9 \mathrm{~kg} / \mathrm{yr}$ and the SSB approach were 3,943.9, $11,157.6$, and $5,831.8 \mathrm{~kg} / \mathrm{yr}$ for farms 1,2 and 3, respectively. The SSB approach showed that hydrologic export (leaching and runoff) and atmospheric loss (volatilization and denitrification) were the two dominant pathways of $\mathrm{N}$ outputs, accounting for approximately $53.2 \%$ and $45.9 \%$ of the total $\mathrm{N}$ outputs (average), respectively. Crop harvesting accounted for only a small portion of $\mathrm{N}$ outputs (approximately $0.7 \%$ ).

Similarly, a fairly large difference in the $\mathrm{P}$ budget using the GNB approaches and SSB approach was observed. Based on the GNB approaches, the total P inputs to farms 1, 2, and 3 were approximately $1,963.5,5,031.0$, and $4,207.8 \mathrm{~kg} / \mathrm{yr}$, respectively and SSB approach estimated the P inputs as 81.5 ,
$1,212.9$, and $1,030.0 \mathrm{~kg} / \mathrm{yr}$, respectively. P inputs from livestock manure/compost were the dominant source of nutrient in the farms. Other sources such as chemical fertilizers, planting materials and atmospheric deposition accounted for a relatively small amount of the total inputs. The total $\mathrm{P}$ outputs for farms 1, 2, and 3 using the current GNB approach were approximately $5.9,19.2$, and $14.9 \mathrm{~kg} / \mathrm{yr}$, respectively; the ideal GNB approach were $-34.9,-27.3$, and $219.3 \mathrm{~kg} / \mathrm{yr}$, respectively and the SSB approach were about 40.7, 537.1, and $454.7 \mathrm{~kg} / \mathrm{yr}$, respectively. The negative outputs found in the ideal GNB for the farms 1 and 2 implies that $P$ removal from the soil P stocks. The SSB approach identified that $\mathrm{P}$ export in leaching was the major pathway of $\mathrm{P}$ outputs, accounting for about $76.7 \%$ (average) of the total $\mathrm{P}$ outputs. Of the total P outputs, on an average approximately $16.1 \%$ was lost due to runoff. Crop harvesting was accounted for $7.1 \%$ (average) of the total P outputs.

As expected, all the investigated farms showed nutrient surpluses for $\mathrm{N}$ and $\mathrm{P}$. Nutrient surpluses in the farms are mainly attributed to livestock manure/compost application. Due to differences in system boundaries, a large variation in nutrient surpluses was observed among the budgeting approaches. In both GNB (current and ideal) approaches, nutrient inputs from livestock manure are considered, whereas as mentioned earlier livestock manure is composted before land application in Korea. Therefore, calculated nutrient budgets based on the GNB approaches ultimately showed large nutrient surpluses as the nutrient loss during composting were not taken under consideration while calculating the nutrient inputs. Moreover, the current GNB approach is unable to reflect the effects of different on-farm manure treatment methods on compost production and does not consider the nutrient loss pathways. In case of the ideal GNB approach, it can be used as a comprehensive agri-environmental indicator as it considers the aGNS to reflect the $\mathrm{N}$ loss and shows the potential risk of nutrient surplus to the whole agricultural environment (soil, air, and water). However, the system boundary in the ideal GNB is quite wide and hence requires many data for adequate calculation. Due to lack of data, its contribution to uncertainty is very high and thus difficult to use in managing the nutrients. Furthermore, in the ideal GNB approach, hGNS is not estimated directly rather calculated by deducting aGNS from the gross nutrient surplus. Depending on the manure treatment process, the aGNS varies so as hGNS. The ideal GNB approach therefore cannot depict real nutrient loss. Moreover, the manure management system in Korea is not only limited to solid-liquid separation and composting, but it also includes efforts towards reducing the odor using absorption tower, biofilter, biocurtain etc. So, not all the $\mathrm{N}$ lost through denitrification and volatilization are not entering the atmosphere, a portion of $\mathrm{N}$ is captured by the odor reduction facilities. So, there is always a chance 
of overestimating the aGNS in the ideal GNB approach. Despite a detailed approach of calculating nutrient balance, the ideal GNB approach therefore cannot depict the real $\mathrm{N}$ loss. The same is true for $\mathrm{P}$ also. Although unlike N, P cannot be lost during the manure treatment and composting atmospherically; rather it reacts with other cations and precipitates as struvite. Struvite either deposits on the digester or form scales in the pipes during the closed manure treatment system. In both GNB approaches, P removal through struvite precipitation and loss due to scale formation are not considered. Whereas the SSB approach focuses only on the soil environment. It is a nutrient budgeting approach providing sufficient information on nutrient inputs and outputs, nutrient recycling process and dominant nutrient loss pathways. The SSB approach considers the amount of nutrient applied to the soil after manure treatment as solid and liquid compost. Thereby the difference in the nutrient inputs by the different manure recycling and treatment processes method can be considered directly. Although the nutrient loss to the atmosphere before the application is not considered in the SSB approach, the dominant nutrient loss pathways from after application can easily be identified. The SSB approach also shows the partitioning among different nutrient loss pathways and storage or depletion of nutrients within the soil system. From the above discussion, it can be said that, although the ideal GNB is a detailed nutrient budgeting approach depicting the impact of nutrients produced in the mixed crop swine farms on overall agricultural environment, the SSB approach appears to be a reasonable budgeting approach suitable for the mixed crop-swine farms in Korea and more appropriate for the farmers for efficient nutrient management.

Effect of manure treatment methods on nutrient

\section{loading and budgets}

Nutrient inputs in agroecosystems above requirements result in nutrient surplus and are one of the main causes of eutrophication in freshwater ecosystems. Intensive livestock farming systems without appropriate manure recycling processes and treatment methods generate large nutrient surpluses [22]. In this study, the SSB approach revealed that on an average approximately $22.1 \%$ of applied $\mathrm{N}$ and $53.9 \%$ of the applied $\mathrm{P}$ was retained in the farms as surpluses and compost was the dominant source of nutrient inputs. Hence, we quantified and compared $\mathrm{N}$ and $\mathrm{P}$ produced from swine manure through different recycling processes and treatment methods using nutrient loading fluxes reported by Won et al [6] to suggest an effective on-farm treatment method for reduction of nutrient loading to soil (Table 8).

For liquid composting, changing to the aeration method from intermittent to continuous reduced the $\mathrm{N}$ and $\mathrm{P}$ loading about $50 \%$ and $47 \%$, respectively. These findings are supported by previous studies [23]. Factors such as influent characteristics, $\mathrm{pH}$, molar ratio of $\mathrm{NH}_{4}, \mathrm{PO}_{4}$, and $\mathrm{Mg}$, aeration and temperature control nutrient removal from swine wastewater [24]. Among the above-mentioned factors, aeration plays a significant role in nutrient removal. Continuous aeration influences the wastewater $\mathrm{pH}$ by $\mathrm{CO}_{2}$ stripping and thus improves the removal efficiency of nutrients [25]. As CA during liquid composting increases $\mathrm{pH}$, struvite can be formed in alkaline conditions. Struvite produced in the digester either precipitates or forms scale in the piping system as described above. Such struvite cannot be applied in the arable lands but plays an important role in removing nutrients from the liquid manure. Based on the removal efficiency, the CA method during liquid composting is suggested.

Turning (T) only and TA, are the two methods used by

Table 8. Nutrient loading of different on-farm manure treatment methods for the study farms

\begin{tabular}{|c|c|c|c|c|}
\hline \multirow{2}{*}{ Farm } & \multirow{2}{*}{\multicolumn{2}{|c|}{ Recycle processes and treatment methods }} & \multicolumn{2}{|c|}{ Nutrient loading (kg/yr) } \\
\hline & & & $\mathrm{N}$ & $\mathbf{P}$ \\
\hline \multirow[t]{3}{*}{ Farm 1} & Liquid composting & Intermittent aeration ${ }^{1)}$ & $5,031.1$ & 72.6 \\
\hline & & Continuous aeration & $2,515.6$ & 38.7 \\
\hline & & Storage only & $6,482.4$ & 440.2 \\
\hline \multirow[t]{5}{*}{ Farm 2} & Solid composting & Turning and aeration ${ }^{1)}$ & $1,363.8$ & $1,022.9$ \\
\hline & & Turning & $1,960.7$ & $1,001.7$ \\
\hline & Liquid composting & Intermittent aeration ${ }^{1)}$ & $12,832.6$ & 185.1 \\
\hline & & Continuous aeration & $6,416.2$ & 98.7 \\
\hline & & Storage only & $16,533.9$ & $1,122.8$ \\
\hline \multirow[t]{5}{*}{ Farm 3} & Solid composting & Turning and aeration & $1,259.8$ & 944.8 \\
\hline & & Turning ${ }^{1)}$ & $1,810.9$ & 925.2 \\
\hline & Liquid composting & Intermittent aeration & $11,102.5$ & 160.1 \\
\hline & & Continuous aeration" & $5,551.2$ & 85.4 \\
\hline & & Storage only & $14,305.1$ & 971.5 \\
\hline
\end{tabular}

$\mathrm{N}$, nitrogen; P, phosphorus.

${ }^{1)}$ Treatment methods used by the farms. 
the swine farms in Korea for solid composting. Table 5 shows that change in treatment method from $\mathrm{T}$ to $\mathrm{TA}$ improved the $\mathrm{N}$ removal efficiency by $30.5 \%$, while $\mathrm{P}$ removal efficiency decreased by $2.1 \%$. A similar phenomenon was reported by Zhang and He [26]. Due to microbial nitrification and atmospheric loss through denitrification and ammonia volatilization, $\mathrm{N}$ concentration decreased in the solid compost using the TA method [27]. Unlike N, P is less mobile in the environment and less susceptible to loss during the composting process. Therefore, the TA method of solid composting resulted in decreased $\mathrm{N}$ loading, while $\mathrm{P}$ loading remained almost the same. Considering the decrease in $\mathrm{N}$ loading we therefore support the use of the TA method of solid composting over the T method.

Furthermore, the impacts of suggested treatment methods on nutrient budgets were evaluated by developing soil system $\mathrm{N}$ and $\mathrm{P}$ budgets for the study farms (CA for liquid composting and TA for solid composting) (Tables 9, 10). The results showed that changing swine manure treatment methods significantly reduced the farm nutrient surpluses. For farm 1 , change in manure treatment method resulted in $49.4 \%$ and $47.6 \%$ reduction in $\mathrm{N}$ and $\mathrm{P}$ surplus, respectively. While for farm 2, 44.6\% and 7.3\% reduction in surplus was observed for $\mathrm{N}$ and $\mathrm{P}$, respectively. For farm 3, although the $\mathrm{N}$ surplus decreased by $7.4 \%$, the $\mathrm{P}$ surplus increased by $1.9 \%$.

Table 9. Soil N budgets for the mixed crop-swine farm systems using suggested manure treatment methods in this study

\begin{tabular}{|c|c|c|c|}
\hline \multirow{2}{*}{ Items } & \multicolumn{3}{|c|}{ Amount (kg N/yr) } \\
\hline & Farm-1 & Farm-2 & Farm-3 \\
\hline \multicolumn{4}{|l|}{$\mathrm{N}$ inputs } \\
\hline Planting materials & 0.3 & 7.9 & 4.6 \\
\hline Chemical fertilizer & 8.0 & - & 16.0 \\
\hline \multicolumn{4}{|l|}{ Compost } \\
\hline Liquid compost & $2,515.6$ & $6,416.2$ & $5,551.2$ \\
\hline Solid compost & - & $1,363.9$ & $1,259.8$ \\
\hline Biological N fixation & 9.9 & 49.5 & 34.8 \\
\hline Atmospheric deposition & 15.9 & 79.5 & 55.8 \\
\hline Total inputs & $2,549.43$ & $7,909.99$ & $6,918.28$ \\
\hline \multicolumn{4}{|l|}{ N outputs } \\
\hline Crop harvesting & 26.4 & 88.6 & 68.4 \\
\hline \multicolumn{4}{|l|}{ Denitrification } \\
\hline Chemical fertilizer & 1.2 & & 2.4 \\
\hline Compost & 327.0 & 1011.4 & 885.4 \\
\hline Arable land & 1.9 & 9.9 & 7.9 \\
\hline \multicolumn{4}{|l|}{ Volatilization } \\
\hline Chemical fertilizer & 1.2 & - & 2.2 \\
\hline Compost & 578.6 & $1,789.4$ & $1,566.5$ \\
\hline Leaching & 675.6 & $2,096.1$ & $1,833.3$ \\
\hline Runoff & 382.4 & $1,186.5$ & $1,037.7$ \\
\hline Total outputs & $1,994.3$ & $6,181.9$ & $5,403.9$ \\
\hline Balance (surplus) & 555.1 & $1,728.0$ & $1,514.3$ \\
\hline
\end{tabular}

$\mathrm{N}$, nitrogen.
Table 10. Soil $P$ budgets for the mixed crop-swine farm systems using suggested manure treatment methods in this study

\begin{tabular}{lccc}
\hline \multirow{2}{*}{ Items } & \multicolumn{3}{c}{ Amount (kg P/yr) } \\
\cline { 2 - 4 } & Farm-1 & Farm-2 & Farm-3 \\
\hline P inputs & & & \\
$\quad$ Planting materials & 0.5 & 3.0 & 2.0 \\
$\quad$ Chemical fertilizer & 8.0 & - & 16.0 \\
$\quad$ Compost & & & \\
$\quad$ Liquid compost & 38.7 & 98.7 & 85.4 \\
$\quad$ Solid compost & - & $1,023.0$ & 944.8 \\
$\quad$ Atmospheric deposition & 0.4 & 1.9 & 1.4 \\
$\quad$ Total inputs & 47.6 & $1,126.6$ & $1,049.6$ \\
P outputs & & & \\
$\quad$ Crop harvesting & 5.90 & 19.20 & 14.90 \\
$\quad$ Leaching & 16.78 & 397.25 & 370.09 \\
$\quad$ Runoff & 3.53 & 83.48 & 77.78 \\
$\quad$ Total outputs & 26.21 & 499.94 & 462.77 \\
Balance (surplus) & 21.38 & 626.70 & 586.84 \\
\hline P.
\end{tabular}

P, phosphorus.

\section{Management of surplus nutrients}

Effective management of surplus nutrients while achieving agro-economic sustainability and crop productivity poses many challenges. Due to rapid industrialization and urbanization, arable land in Korea is decreasing. Like other countries, farmers in Korea are therefore shifting towards high fertilizer (chemical and compost) input-based farming systems to ensure productivity. Farmers generally think that the more fertilizer they use, higher yield and profit will result. Intensive agricultural practices in Korea started during the mid-1980s and increased until the mid-1990s. Due to the development of national soil fertility database, decision-support system for farmers and promotion of eco-friendly agricultural policies, FA decreased from 689,901 metric tons in 2002 to 450,453 metric tons in 2016 [5]. However, the numbers are still higher than the most OCED member states. Recent $\mathrm{N}$ and $\mathrm{P}$ budget studies reported that FA rate for highland crops in Korea is more than 1.5 and 4.5 times, respectively higher than the recommended rate $[8,9]$. Such activities resulted in the retention of surplus nutrients on arable land. Hence, while managing the surplus nutrients along with the environmental aspects, the social and economic perspective should be considered. The fertilizer (chemical and compost) application rate to the crop fields often determined based on crop $\mathrm{N}$ requirement [28]. As a result, $\mathrm{P}$ may be applied above the crop P demand and retained in the soil. The retained $\mathrm{P}$ can be released in the future due to hydrologic, geologic, climatic events or changes in land management practices and can amplify $\mathrm{P}$ related environmental problems.

Moreover, the buildup of large nutrient surpluses from nutrients in animal feeds is another major issue in countries with intensive livestock production like Korea. Goulding et 
al [29] reported that low conversion efficiency of nutrients in animal feeds lead to loss of nutrient through excretion. For efficient nutrient management in Korea, swine farms either need to treat the manure using on-farm treatment facilities or send the wastewater to the centralized treatment plants before discharge into water bodies [30]. The operational cost of the farms having on-farm manure treatment processes is higher than the farms having a simple storage facility. Considering the reduction in nutrient content, postmanagement cost, social cost and environmental benefits, composting is an effective way to treat the manure. The farms already having composting facilities required no further investment in infrastructure development except installing the aeration system for solid composting. However, operational cost of liquid and solid composting by CA and TA, respectively might be higher than IA and turning. Acknowledging the environmental sustainability and long-term benefits, the Korean government could develop policy and provide subsidies to encourage the farm owners to change the onfarm treatment facilities. Therefore, improving on-farm manure treatment methods along with additional policies (tested and successful in other parts of the world) such as nutrient recovery from wastewater, reutilizing recovered nutrients as fertilizer and feed additives, extensive and organic farming systems, cultivating high yielding varieties for efficient use nutrients, precision farming, distributing compost in nearby specialized croplands, restricting maximum application limit and time, incentives for achieving balance and comprehensive nutrient management plans could be useful in reducing the nutrient surpluses in mixed crop-swine farms [29].

\section{IMPLICATIONS}

The soil system budgeting approach considers all the possible nutrient inputs and identifies the dominant nutrient loss pathways and can therefore be considered as a rational budgeting approach for the mixed crop-swine farms. Combination of continuous aeration for liquid composting and turning+ aeration for solid composting can reduce the nutrient loading to the soil and nutrient surpluses. The findings of this research have several important implications for nutrient management for future practice. However, sensitivity analysis of the fluxes used in this study, economic analysis of the suggested on-farm manure treatment methods and more field studies are required for better understanding and reliability of the soil system budget approach in the Korean context.

\section{CONFLICT OF INTEREST}

We certify that there is no conflict of interest with any financial organization regarding the material discussed in the manu- script.

\section{ACKNOWLEDGMENTS}

This research was funded by the Rural Development Administration of Korea (Project number, PJ011623) and partially supported by Kangwon National University. We also would like to thank the farm owners for providing information.

\section{REFERENCES}

1. Ryschawy J, Choisis N, Choisis JP, Joannon A, Gibon A. Mixed crop-livestock systems: an economic and environmentalfriendly way of farming? Animal 2012;6:1722-30. https:// doi.org/10.1017/S1751731112000675

2. Oenema $\mathrm{O}$, Kros H, de Vries W. Approaches and uncertainties in nutrient budgets: implications for nutrient management and environmental policies. Eur J Agron 2003;20:3-16. https:// doi.org/10.1016/S1161-0301(03)00067-4

3. Goodlass G, Halberg N, Verschuur G. Input output accounting systems in the European community - an appraisal of their usefulness in raising awareness of environmental problems. Eur J Agron 2003;20:17-24. https://doi.org/10.1016/S11610301(03)00068-6

4. Fernall D. Soil nutrient balances: reviewing and developing to meet customer needs [Internet]. OECD; 2010 [cited 2019 Feb 20]. Available from: http://www.oecd.org/greengrowth/ sustainable-agriculture/44793491.pdf

5. Statistics Korea: Investigation of Agriculture, Forestry and Fisheries [internet]. Daejeon, Korea: Statistics Korea; 2019 [cited 2019 May 10]. Available from: http://kosis.kr/statis ticsList/statisticsListIndex.do?menuId=M_01_01\&vwcd= MT_ZTITLE\&parmTabId=M_01_01\&statId=1968004\&th emaId=F\#F_5.2

6. Won S, You BG, Shim S, Ahmed N, Choi YS, Ra C. Nutrient variations from swine manure to agricultural land. AsianAustralas J Anim Sci 2018;31:763-72. https://doi.org/10.5713/ ajas.17.0634

7. Bashkin VN, Park SU, Choi MS, Lee CB. Nitrogen budgets for the Republic of Korea and the Yellow Sea region. In: Boyer EW, Howarth RW, editors. The nitrogen cycle at regional to global scales. Dordrecht, The Netherlands: Springer; 2002. pp. 387-403. https://doi.org/10.1007/978-94-017-3405-9_12

8. Kettering J, Park JH, Lindner S, Lee B, Tenhunen J, Kuzyakov Y. $\mathrm{N}$ fluxes in an agricultural catchment under monsoon climate: a budget approach at different scales. Agric Ecosyst Environ 2012;161:101-11. https://doi.org/10.1016/j.agee.2012.07.027

9. Reza A, Eum J, Jung S, et al. Phosphorus budget for a forestedagricultural watershed in Korea. Water 2019;11:4. https://doi. org/10.3390/w11010004

10. Ministry of Environment (MoE): Data on livestock manure treatment [Internet]. Suwon, Korea: Ministry of Environment; 
2008 [Cited 2018 Dec 13]. Available from: http://www.me.go. $\mathrm{kr} /$ home/web/policy_data/read.do?menuId=10263\&seq=6257

11. Ministry of Environment (MoE). Study on the characteristics of regional scale wet and dry acid deposition (I). Suwon, South Korea: Ministry of Environment; 2014.

12. Kim T, Kim G, Kim S, Choi E. Estimating riverine discharge of nitrogen from the South Korea by the mass balance approach. Environ Monit Assess 2008;136:371-8. https://doi.org/ 10.1007/s10661-007-9692-4

13. Kang J, Amoozegar A, Hesterberg D, Osmond DL. Phosphorus leaching in a sandy soil as affected by organic and inorganic fertilizer sources. Geoderma 2011;161:194-201. https://doi. org/10.1016/j.geoderma.2010.12.019

14. Reza A, Eum J, Jung S, Choi Y, Owen JS, Kim B. Export of non-point source suspended sediment, nitrogen, and phosphorus from sloping highland agricultural fields in the East Asian monsoon region. Environ Monit Assess 2016;188:692. https://doi.org/10.1007/s10661-016-5681-9

15. Kremer AM. Nutrient budgets-methodology and handbook, Version 1.0.2. Luxembourg: Eurostat and OECD; 2013.

16. Bouwman AF, Boumans LJM, Batjes NH. Estimation of global $\mathrm{NH}_{3}$ volatilization loss from synthetic fertilizers and animal manure applied to arable lands and grasslands. Glob Biogeochem Cycle 2002;16:8-1-8-14. https://doi.org/10.1029/2000GB 001389

17. Rural Development Administration (RDA). Fertilizer application guideline to crops (Revised edition). Suwon, Korea: Rural Development Administration; 2010.

18. Rural Development Administration (RDA): Feed ingredients standard in Korea [Internet]. Jeonju, Korea: Rural Development Administration; 2012 [Cited 2019 Jun 20]. Available from: http://www.nongsaro.go.kr/portal/ps/psf/psfa/feed SchDtl.ps?pageIndex $=1$ \&pageSize $=10 \&$ menuId $=$ PS00254 \&feedMenuId=PS00254\&hsrrlManageNo=S150223223821 352\&sType $=\& s$ Text $=\% \mathrm{ED} \% 86 \% \mathrm{~B} 1 \% \mathrm{~EB} \% \mathrm{~B} 0 \% \mathrm{~A} 5$

19. Rural Development Administration (RDA). Korean food composition table (9th revision). Jeonju, Korea: Rural Development Administration; 2016.

20. Rural Development Administration (RDA): Soil test information [Internet]. Wanju, Korea: National Institute of Agricul- tural Sciences; 2018 [Cited 2019 Jun 20]. Available from: http:// soil.rda.go.kr/soil/sibi/sibiExam.jsp

21.Takakai F, Kikuchi T, Sato T, et al. Changes in the nitrogen budget and soil nitrogen in a field with paddy-upland rotation with different histories of manure application. Agriculture 2017;7:39. https://doi.org/10.3390/agriculture7050039

22.Chadwick DR, Chen S. Manures. In: Haygarth PM, Jarvis SC, editors. Agriculture, hydrology and water quality. Wallingford, UK: CABI; 2002. p. 57-82.

23.Luo A, Zhu J, Ndegwa PM. Removal of carbon, nitrogen, and phosphorus in pig manure by continuous and intermittent aeration at low redox potentials. Biosyst Eng 2002;82:209-15. https://doi.org/10.1006/bioe.2002.0071

24. Rahman MM, Salleh MAM, Rashid U, Ahsan A, Hossain MM, Ra CS. Production of slow release crystal fertilizer from wastewaters through struvite crystallization-a review. Arab J Chem 2014;7:139-55. https://doi.org/10.1016/j.arabjc.2013. 10.007

25.Suzuki K, Tanaka Y, Kuroda K, et al. Removal and recovery of phosphorous from swine wastewater by demonstration crystallization reactor and struvite accumulation device. Bioresour Technol 2007;98:1573-8. https://doi.org/10.1016/ j.biortech.2006.06.008

26.Zhang Y, He Y. Co-composting solid swine manure with pine sawdust as organic substrate. Bioresour Technol 2006;97: 2024-31. https://doi.org/10.1016/j.biortech.2005.10.004

27. Martins O, Dewes T. Loss of nitrogenous compounds during composting of animal wastes. Bioresour Technol 1992;42: 103-11. https://doi.org/10.1016/0960-8524(92)90068-9

28. Eghball B. Soil properties as influenced by phosphorus- and nitrogen-based manure and compost applications. Agron J 2002;94:128-35. https://doi.org/10.2134/agronj2002.1280

29. Goulding K, Jarvis S, Whitmore A. Optimizing nutrient management for farm systems. Philos Trans R Soc Lond B Biol Sci 2007;363:667-80. https://doi.org/10.1098/rstb.2007.2177

30. Reza A, Shim S, Kim S, Ahmed N, Won S, Ra C. Nutrient leaching loss of pre-treated struvite and its application in sudan grass cultivation as an eco-friendly and sustainable fertilizer source. Sustainability 2019;11:4204. https://doi.org/ $10.3390 /$ su11154204 